\title{
Conflict: Efficient State or State Under the Rule of Law? - The Hungarian Case of the Victory of the Efficient State over the State Under the Rule of Law
}

\author{
Maria BORDÁS \\ National University of Public Service, Budapest, Hungary
}

\begin{abstract}
This study is seeking an answer as to whether the efficient state and the state under the rule of law are indeed irreconcilable, as well as to whether these two categories are by nature to be seen as contrary concepts. The basic issue is whether efficiency is to be handled as an "extralegal" category, or whether legal regulation, in accordance with public administration traditions in Europe, can in itself meet the requirement of efficiency. Also the study presents the formation of the issue of conflict between the effective state and the state under the rule of law in Hungary after the election held in 2010 in the practice of economic policy and legislation of the Orban government. We are trying to answer the question of the tendency of power concentration to really menace the principles of a traditionally-formed state under the rule of law, as well as whether the economic policy of the government can be implemented effectively in a strongly centralized political and state administrative system.
\end{abstract}

Keywords: Efficient state, rule of the law, constitutionalism, New Public Management, neoliberalism, Weberian model, constitutionalism, economic governance

\section{Introduction}

This study is seeking an answer as to whether the efficient state and the state under the rule of law are indeed irreconcilable, as well as to whether these two categories are by nature to be seen as contrary concepts. The basic issue is whether efficiency is to be handled as an "extralegal" category, or whether legal regulation, in accordance with public administration traditions in Europe, can in itself meet the requirement of efficiency.

To answer the aforementioned question is the main contribution of this study. This has been an especially debated issue in the European literature of public administration since the 1980s, when the American management approach based on the neoliberal economic policy was introduced in the so called Weberian model in Europe.

The most important features of the Weberian model of public administration were identified by Max Weber, a European scientist of public administration. According to his theory, the European public administration is typified as a centralized, hierarchical and law-governed system. This kind of public administration developed at the beginning of the liberal capitalism as a reaction of the feudal absolutism. The government in this administrative system is allowed to act only if it is regulated by laws. The laws heavily

Maria Bordas, Professor, Ph.D., Department of Public Policy and Public Administration Development, National University of Public Service. 
regulating the public administration protect in this way the individuals and the business firms from the autocratic intervention of the government.

As a result of the crisis of neoliberal economic policy, the New Public Management emphasizing efficiency and arguing for a drastic reduction of the state's role in the past decades has been increasingly seen as the factor responsible for the development of a weak state with limited power, incapable of control. In this sense the efficient state is more and more understood to also be a strong state, solving problems of public interest firmly and fast.

In the neo-Weberian model, now in the process of being formed, European states develop institutions that make the functioning of the state more efficient. At the same time they adhere to the traditions and the framework of European public administration, acknowledging the fact that the business and management methods applied in the American public administration in their original form cannot be applied in the European civil service systems, while the Weberian model is outdated and not suited to efficiency requirements.

Also the study presents the formation of the issue of conflict between the effective state and the state under the rule of law in Hungary after the election held in 2010 in the practice of economic policy and legislation of the Orban government.

The main purpose of the study is to answer the question of the tendency of power concentration to really menace the principles of a traditionally-formed state under the rule of law, as well as whether the economic policy of the government can be implemented effectively in a strongly centralized political and state administrative system.

Analyzing the practice of the Orban government from this perspective in the form of a case study gives a good chance to answer the basic question of this article, if the limitation of the state under the rule of law may lead to a more efficient public administration, or only the inefficient governance lacking the basic democratic values.

\section{The Background of the Conflict Between the Efficient State and the State of the Rule of Law in Hungary in the Practice of the Orban Government Since 2010}

Two of the most disputed questions in Hungarian public life are whether the current practice of the government obstructs its own efforts aimed towards efficiency and the principle of whether a state created under the rule of law can be overwritten by the aspects of efficient states?

In 2010 the Hungarian Parliament amended the Constitution to limit the Constitutional Court's jurisdiction in order to place budgetary issues and taxes outside the court's scope of review.

Following the constitutional amendment of 2010, critical remarks were made in numerous conferences and interviews regarding the government jeopardizing the rule of law by curbing the Constitutional Court's jurisdiction. According to one argument, limitations on the Constitutional Court's jurisdiction violated the principle of separation of powers and that the amendment abused the ruling party's two-thirds majority within the Parliament, because it is against the historically developed basic constitutional principles (Chronowski, Drinóczi, \& Zeller, 2010). The representatives of legal sciences generally hold that the efficient state may not override the rule of law, i.e., the ends may not justify the means.

The Government initiated a new Constitution in 2011 using the opportunity of its two-third majority in the Parliament. The new Constitution even more limited the scope of the Constitutional Court, which means that it does not have sufficient jurisdiction for constitutional supervision over legislation anymore. It has been a 
practice in the legislation that if an act had concern vis-à-vis Constitution, the Parliament amends the new Constitution and put this legal provision to the new Constitution. This is because the Constitution cannot be supervised by the Constitutional Court in any way and the Government can implement its decisions without any limitation in this way.

The government's recent economic policy lays great emphasis on creating an efficient state by improving budget indicators, managing the state debt, rationally utilizing public funds, curbing corruption or by offering public administration online. To achieve this efficiency, the government must execute policy in a fast and efficient way; the government has attained a huge concentration of power in the state machinery. Thus, the requirements for an efficient state and for a state under the rule of law seem to contradict each other, at least on the surface.

From a scientific standpoint, which has been quite frequently announced, the government has eliminated some institutions ${ }^{1}$ of the state under the rule of law by the abolition of checks and balances.

Meanwhile politicians of the Government have underlined that the Government, under the powers of their elected office, justified the changes in law by the two-thirds majority and the need for economic policy change and goals. ${ }^{2}$

The arguments most frequently announced by the impugners of the state under the rule of law's elimination, are the limitation of Constitutional Court's scope of authority, the placement of court jurisdiction under political control, and the removal of the counterbalancing roles of the Parliament, President, Constitutional Court, and other controlling authorities, such as State Audit Office, Central Bank, ombudsman, etc.. These checking actions were replaced with steering committees and pro-government leaders. According to the counterarguments stressed by Government, the state has a right to determine its own constitution. And based on this, it may lay down new laws to appoint the structure, context and content of the state system.

The international legal norms that limit this right of a state as well as international organizations and foreign politicians, have called upon the Hungarian Government to address this problem. However, these norms are legal principles that have been formed in generic way so that judgment of Hungarian legal institutions is fit according to these norms; it is really a question of legal interpretation. ${ }^{3}$ Another point is if the Hungarian Government does not accept the more accepted legal interpretation, the European Union may choose to coerce the Hungarian Government through application of legal and other informal

\footnotetext{
${ }^{1}$ Kornai (2012) explains that there is a wide agreement among the critics of the Government-which he also agrees with. Hungary is no longer a democracy, but instead an autocracy. The state, under the rule of law, has been weakened and the human rights violated by the autocratic governance during the last two years. The aim, from the onset of the Government, in his opinion, was to establish unlimited political power, instead of implementation of economic policy by using centralization as a tool.

2 Janos Lazar, the floor leader of the governing party in the Parliament, said: "These are not elegant, but necessary answers (i.e. the practice of the legislation in the Parliament) I do not want to avoid discussions, just to turn them in a reasonable channel, while we have to take efficiency requirements into account, as well. We have to take actions quickly, while huge ships should be navigated to the right direction. A consensual democracy based on the agreement of the political parties' agreement developed in 1989-1990., with the help of the US. This, however, does not mean that only such a type of democracy can exist in Hungary. We do think in the FIDESZ (the political party on power in Hungary) that the majority democracy is more efficient and faster, at the same time can assure a clearer accountability in politics (Andras Kosa-M. Ferenc Laszlo: Rather this, than a decree-based governance - Janos Lazar about the reasons of the power-politics". Interview with Janos Lazar. hvg.hu, December 26, 2011).

3 The question if the Hungarian laws violate any legal principle of the European Union, could be explained in more details, however, we do not do so. The inquiry, initiated by the European Commission in this matter is still pending. The European Council called upon the Hungarian Government in 2013 to amend numerous provisions of its new Constitution in accordance with the European democratic principles. The US government authorities also expressed their aversion to the political and constitutional practice of Hungarian Government referred to the violation of the separation of power, free media, etc..
} 
means. ${ }^{4}$ Constitution and the so-called "pivotal laws" (laws of key importance) do not mentioned such public service institution which has not reference from the international practice: There is a European country where the Constitutional Court simply does not exist, or it has a very limited scope of authority, also there is a model of jurisdiction where the Ministry of Justice is on the top or where the bank of issue and financial controlling functions are executed by the same organization. Hence, it is disputable that the principles of state under the rules of law are harassed or not and one can argue that the changes in the state organization are showing a tendency of power concentration.

But there is no template or gauge by virtue of which one can doubtlessly determine that the concentration of power has already passed the tipping point in terms of a system of checks and balances. ${ }^{5}$

It is difficult to argue against the practice of promoting heads of central organizations if the parliament, particularly the ruling majority in the parliament, is the authority for these actions.

The arguments most frequently voiced by the political challengers of the elimination of the state under rule of law is the most important principle of checks and balances, which is not formally functioning within the current system. ${ }^{6}$

Even so it is obvious the pertinence of this view the current ruling parties having two-thirds majority in Parliament in accordance with the Constitution and other laws, are able to make changes without concern for public approval, also have authorization to change and transform the state build up, so this cannot be challenged from the public legal point of view. The general public does not have the legal standing to challenge the modifications to the government, according to the constitution.

There is an analysis which is passing limitations upon the lack of constitutional culture and arguing against the legal restrictions. ${ }^{7}$ Politicians of the European Union more and more are criticizing the intellectuality of the new Constitution and pivotal laws which, according to their opinion, are contrary to the democratic tradition of European political systems. ${ }^{8}$ The reference to the European constitutional culture and

\footnotetext{
${ }^{4}$ Institutions of the European Union-i.e. the European Commission and the European Court-have the right to decide if a member country has violated the EU laws, and as a consequence can prescribe legal sanctions. This can take years. The European Commission may force the Hungarian Government to amend the laws through the removal of credit.

5 The Venice Committee, an organization of the European Council, identified this in its report 614/2011 on March 28, 2011. It could answer only those three questions related to the new proposed Constitution that were asked by the Hungarian Government. However, the committee could not form an opinion on other issues because the draft of the new Constitution had not yet arrived. The Venice Committee criticized the Hungarian Government for reducing the scope of its Constitutional Court and declared that checks and balances should not be relegated to mediocrity. Consequently, it had to admit that the latter issue should be within the power of the nations, in other words, they have the right to determine state organization on the basis of their interpretation on the principle of checks and balances. The Venice Committee is currently inquiring on 8 basic acts passed by the Hungarian Parliament.

${ }^{6}$ Kim Lane Scheppele, the professor of constitutional law at the Princeton University, also an expert of the Hungarian constitutional law, stated in several interviews that the recent modifications to the Hungarian state cannot ensure democratic governance. According to her opinion, the Hungarian state has already becoming a dictatorship, at the same time it is going to stop being a state operating under the rule of law. Also, the US Government has expressed on many occasions its concern about the destruction of the democracy and the state under the rule of law.

${ }^{7}$ Laszlo Solyom, the former president of the Constitutional Court and former president the Republic of Hungary, explains in his study, "Chances of the constitutionalism" (HVG Volume 1/2012. p. 20) that the attitude of the Government toward constitutionalism can be typified by the lack of constitutional culture. According to his opinion, the political power in the countries having constitutional culture is not the question of the freedom of brute force. This is why constitutionalism requires an emotional and intellectual culture. Only barbarians and fundamentalists read a holy book literally. This is the case with the constitutions, as well. The Government, having majority in the Parliament, uses the constitution purely as a means to implement its political goals. This shows such an attitude of the Government that thinks its power cannot be hindered in any way, even by the constitution (HVG Volume 1/2012, p. 20).

8 Jose Manuel Barroso, the president of the European Commission, called to the attention of the Hungarian prime minister at the European Parliament that a member-state has to respect the spirituality and the basic democratic principles of the EU, as well, not just to meet in its national legislation but also the requirements of the European Union laws.
} 
democratic traditions can be challenged and requested from governmental parties only politically but not from a legal point of view.

The arguments of the two sides are at cross-purposes. It is fact that during the last few years, the principle of checks and balances has been less predominant in the Hungarian public legal system than in prior years. From the one side, the lack of checks and balances was determined to be a grave handicap for democracy and the state, possibly due to a limited culture of politics and constitutionality.

Representatives from the other side argued that it is just using the legal authorities legitimized by the two-third parliamentary majorities and needed for the effective execution of the governmental program.

The two sides argue that the elimination of checks and balances is either a Hungarian specialty in the public legal system or just an abuse and breach of trust of electors; the change is argued as a rational political decision or, on the contrary, represents a grave lack of democracy - this debate between two sides became endless.

Hereinafter we are trying to provide an answer to the question of how the Government used legal regulatory tools during its almost four years of work to affect economic policy; these changes can be observed in the institutions of state under the rules of law in order to consider the aspects of efficiency that may have been achieved.

\section{The Concept of the State Under the Rule of Law}

The term "rule of law", in its most general meaning, refers to government power being subject to law. According to one interpretation of the rule of law, which evolved in the liberal capitalism of Europe, state bodies may only proceed as authorized by law, performing only what is statutorily authorized and in the way authorized (Lörincz, 2010a).

In that meaning, acts of parliament became the main source of law, to be implemented by the civil service, i.e. the civil service may only make decrees in accordance within the framework of those acts of parliament.

Rule of law, in this interpretation, meant being bound by law and legality. This concept of the rule of law is often referred as the liberal rule of law (Ádám, 1999). State activity, owing to the dual nature of public and private law, was subjected to public law rules to assert the public good on the one hand, and to protect the autonomy of individuals against state intervention, on the other hand.

Public law was expected to govern state activities in detail so that the principle of being bound by statute may be attained as consistently as possible. Public law regulations were further refined along the principles of the legal dogmatism of public administration - the objective being the ever-precise definition and application of legal norms (Lörincz, 1999). In a while, however, this resulted in an over-regulated public administration, with legal regulations being introduced for their own sake, no longer focusing on the actual aim of public administration - solving issues of public significance.

In the American civil service, evolving differently from public law development in Europe, this concept of the rule of law did not come about. In the absence of a central power to oppose, as feudal absolutism was opposed in Europe, the role of the state did not have to be defined, i.e. no legal limitations had to be imposed to check state intervention. Decentralization in the American civil service from the very beginning clearly demonstrated the distrust of the American people of a strong central power. Civil service in America was based on the traditions of self-government and self-organization; the duality of public law-private law did not develop (Lőrincz, 1999). 
In the European liberal approach to the rule of law, parliament's power, that of the body exercising popular sovereignty, was by no means meant to be limited. This liberal approach to the rule of law is formal, since subordination to statutes does not in itself equal the rule of law, when the state exercises unlimited power in determining what is to be regulated by law, and in what manner, under the pretense of parliamentary sovereignty.

The constitutional state under the rule of law, which also establishes the principles for what the rule of law is, in a more general sense sets the requirement for laws to be compatible with the constitution. The constitution, the basic law, formulates values relevant to the times as fundamental rights and basic principles.

Most European constitutions, as their basic principle, comply with the rule of law, with several meanings attached to it by the science of constitutional law and the legal interpretation of that concept by judges of the constitutional court. As far as limited public power is concerned, constitutional rule of law refers to fundamental rights and the separation of powers being governed by the constitution.

In the age of liberal capitalism, prevailing economic thinking has argued for the non-intervention of the state into the economy. As safeguards for this served the economic fundamental rights enshrined in the constitution, this lays down the foundation for the capitalist economic system. Individuals were protected against excessive state interference by political and freedom rights that constitutionally restricting the government.

The need for dividing the powers between the bodies of the state already arose in liberal capitalism, as another rule of law institution in addition to fundamental rights. However, in most European government systems, the risk of the concentration of power is a lingering threat.

Since parliament and the government have the right of election and appointment, the party or parties having won the general elections can indeed dominate not only parliament and the government, but other public bodies as well, especially those headed by one person rather than the corporate ones. When a party has a two-thirds majority in parliament, the possibility of a concentration of power is increasingly there, especially when the two-thirds majority allows amending the constitution, or even creating a new constitution.

The separation of power between branches of government in Europe failed to fulfill the duty of limiting public power, since no balance between them could be reached. The legislative, the executive and the judicial branches became recognized as functions of the state rather than independent branches of power themselves (Sári, 1992). The judiciary, due to its different nature (it is a law applying and not a law-making body), cannot be considered as a governance actor to the same extent as the legislature and executive branches of the government. It is only the constitutional court with its authorization to invalidate laws that can place a real limitation on governmental power.

The government's power in relation to parliament can also become excessive. In the beginning, in accordance with the prevalent view, the executive was subject to the power of the legislature, since it could only execute consistent with laws and create law by its actions. Later, however, it became clear that the legislature was unable to check the government, since with economic-social relations becoming more complicated, parliament possesses less and less the expertise than the government's staff of experts does. Furthermore, beyond acts of parliament, legislation enacted by government is gaining significance, as well.

There is another reason. The government does in fact play the decisive role in legislation: Due to the political entanglements between the government and the parliament, parliament has no interest in truly limiting the public power of government (Sári, 1992, p. 168). Also, in the course of drafting laws, it is the government 
that actually makes the political decision which then, when it is already a law, will only need to be regulated by means of law. There are extraordinary periods when the adoption of laws follows their proposal by members of parliament and not by the government, which is, however, in the normal state of affairs usually not the case, for the professional reasons mentioned before.

From a political perspective, opposition parties, the media, lobby groups, NGOs and public referenda can counterbalance the power of government actors. However, from the perspective of the rule of law, i.e. the limitation of public power, it is the bodies with sufficient public authorization, especially the Constitutional Court, which can indeed offset the power of parliament and the prevalence of the government.

Hence, in the system of government, the focus has shifted more onto the system of checks and balances and not the principle of the separation of powers.

The dominance of the parliament and the government can most successfully be limited by constitutional review (Chronowski, Drinóczi, \& Zeller, 2010), which in compliance with the principles and fundamental rights of the constitution invalidates those statutes incompatible with constitutional provisions. Thus, the constitutional court is the heaviest balance against the prevalence of parliament and the government (Sári, 1992, p.169).

In the American system of government, the separation of powers and the system of checks and balances both operate consistently. In essence, legislative, executive and judicial bodies all exercise certain powers over the other branches. The legislative body, for instance, exercises its executive power when it overrides the presidential veto, while it exercises its judicial power when impeaching (removing) judges. The President can veto laws and appoint judges, while the judicial power can interpret and strike down laws, as well as supervise the action of the executive (Kenneth, Berry, \& Goldman, 1995, p. 79).

In the American system of governance nor is there any serious political entanglement between the legislative and the executive powers, since, the President, on the one hand, and the Senators and the Representatives of Congress, on the other, are elected independently and at different points of time-the presidential advisors, or cabinet secretaries (akin to ministers in most government) are not members of the legislature as well. Thus, the issue of the separation of powers in America, in contrast to the European practice, is not centered around the relationship between two branches of public power but three co-equal branches.

From now on, two aspects of the concept of the rule of law will be our central focus, since these two are relevant to the efficient state: Public administration being bound by law, Constitutional regulation and review.

\section{The Concept of the Efficient State}

Efficiency has been defined by many people in many various ways (Cameron \& Wheten, 1983, pp. 25-30), with one common feature: an activity can be regarded as efficient when the intended outcome is achieved with the lowest possible input and cost.

The efficiency of enterprises is judged by competition in the market: the enterprise with a high input and expenditure becomes uncompetitive and disappears from the market. According to the science of economics, the efficiency of economic processes means that the economy is at its limits, which is also quantitatively measurable.

The definition of the efficient state, however, also raises numerous questions. Firstly, what is the state whose efficiency we wish to measure? By state we can understand the organizations of the state: the legislature, the public administration (executive), the judiciary, and the external supervisory bodies, as well as the system 
of private law organizations discharging state functions.

The judiciary has been left almost untouched by efficiency reforms, ${ }^{9}$ as opposed to public administration, which in past decades has become too much the focus of attention. In general, as regards parliament, the issue of efficiency has not arisen, but as regards the process of legislation it has. The most recent efficiency requirements bestow upon supervisory bodies a prominent role, in particular in the area of management of state property and the utilization of public funds.

Public administration is a public organization of the state that cannot be unambiguously defined, since the public administration does not just include public administration bodies with public mandates. Beyond legislation and the implementation of law by authorities, the civil service also discharges public services, as well as manages state property as well as public funds. It is not clear whether privately-owned enterprises authorized to perform public services, or bestowed with the function of a public body (investment or public activity, e.g., the collection of taxes or law enforcement) also constitute part of the public administration.

The term public sector is used when not only public bodies, but state- or privately owned-private organizations, institutes and business associations, are also included. Henceforward, the term "public administration" will refer to this broader sense of the word.

Another aspect of the efficient state is how the concept of efficiency is to be understood. The efficient state can be either smaller and cheaper, or better organized, which latter requirement embraces both a rational organizational structure and an effective utilization of resources.

If our starting point is that one criteria of efficiency is the lowest possible cost, it can by no means be considered accidental that the neoliberal rhetoric stressing the importance of state efficiency has linked efficiency to the "cheaper and smaller state". We must note, however, that the smaller size and cheaper cost of the state cannot in itself be regarded as the measure of efficiency. This is due to the fact that measuring state efficiency based on smaller size and cheaper cost raises concern. ${ }^{10}$

Firstly, in relation to what is the state to be considered smaller and cheaper? The state operating cheaper than previously does not in itself mean that it is more efficient. Yet, neither is its opposite true: if state expenditure has not or has not substantially decreased, the state cannot in all circumstances be regarded as less efficient.

It is possible that certain state functions could have been removed from state responsibility, state bodies could have been abolished or merged, or part of the workforce could have been made redundant (made smaller). This mechanical means of tightening the state also does not necessarily result in greater efficiency.

A further difficulty in assessing the measure of state expenses is that in defining the state it is not unambiguous, due to private organizations that are attached to the civil service, as we have mentioned earlier.

Consequently, data showing the changes in the relation of state expenses to the GNP are also not a reliable basis for judging whether the state has become substantially smaller and cheaper.

The reason why American neoliberal economic thinking in the 1980s found the welfare state inefficient was that the high taxes that were paying for welfare costs slowed down economic growth and that public services provided by the state are bound to be expensive and of poor quality. American neoliberalism therefore

\footnotetext{
${ }^{9}$ Despite the fact that significant research has been done in Hungary into the efficiency of the judiciary, the operation of the justice system can be considered to be of a very low quality, according to general experience (Fleck, 2008a; Fleck, 2008b).

${ }_{10}$ Lajos Lörincz (2010a, 2010b) expounds his position that the efficiency of the state cannot be unambiguously defined, since neither the aims, nor the means of evaluation are sufficiently clarified. Lajos Lörincz in general held that the efficiency of the state cannot be unambiguously defined, while he acknowledged that methods measuring efficiency needed to be developed.
} 
set as one of its main objectives the target of "more market-less state", which meant that the state was to withdraw from areas, mainly those of public service provision, since they could be better operated by the private business sphere.

The "destatelization" of public service provision occurred in two ways in the US (Bordás, 2009). The main form of the "destatelization" in the US was the privatization. The privatization has several meanings. The privatization in the post-communist countries in Central and Eastern Europe at the beginning of the transition, since the 1990s, was identified as selling the state-owned enterprises, which formed the $95 \%$ of the business sector, to business firms. The term of privatization was used in the US practice by the neoliberal economic policy as the withdrawal of the government from the public sector in the way of the liberalization of the market of the infrastructural services, in other words, privatization aimed to establish market competition in this sector. In the field of those local public services, such as garbage collection, pubic lighting, welfare institutions, etc., where competition could not, or hardly be created, tenders had to be invited, and give the right to provide public services to the applying service provider that offers the best conditions: the lowest price, and the best quality of the service. The privatization in the continental Western European countries was implemented in the way of concession, which gives the exclusive right of the provision of certain public services to private-owned service providers, but the assets connecting to the public service should be maintained in state ownership. This is because the state property is protected by the constitutions of the most continental Western European countries. In Great Britain, where such limitations did not exist, the Thacher government could privatize the most sate-owned enterprises, both in the public and private sector.

In the provision of infrastructural services, the state repealed the restrictions on entry into the markets and generated market competition. Thereby, bodies that were earlier in a monopoly position and regulated enterprises that provided public services became superfluous, since market competition proved much more efficient in regulating the prices and quality of services. The state, thus, was relieved of paying for the sustenance of regulatory bodies, and the state indeed became smaller and less expensive.

Public services and certain public responsibilities so far provided by the state were withdrawn from state responsibility through privatization, which took various courses. At times the state ceased to provide public services or to perform public responsibilities, encouraging individuals to make use of market services. In other instances, when market competition could not be generated, the state would select the most efficient enterprise upon tenders (instead of by market competition) to conclude a contract with service provision or the discharge of state responsibility.

State costs would subsequently decrease: in the former instance the state devolved the costs to individuals, in the latter it devolved the "business risk" to the enterprise, assuming that the interest in gaining profit would operate the public service more efficiently.

In American neoliberal thinking, therefore, one way of realizing the smaller and cheaper state is to subject the provision of public services to market competition, as well as conferring certain public services and public responsibilities onto business enterprises, even if market competition cannot be generated.

Such reduction of the scope of state competences and of state size could be achieved in the American public sector because American business lobbies and the middle classes supported low taxes, while the business sector promoted the acquisition of new markets and the middle classes were in favor of public service provision adhering to the practice of consumer choice. 
In European public administration systems, the withdrawal of the state from the provision of public services did not occur to such a great extent, since in contrast to the American way of thinking, abolishing the state's welfare services and surrendering the principle of solidarity was here unimaginable. Also, in Europe state property linked to the provision of public services is in many ways protected, while in America state property never even developed, on the assumption that it could only be of low efficiency. The European approach, in general, is not in favor of the privatization of public responsibilities.

The smaller and cheaper state developed by the American neoliberal approach actually meant the privatization of public services, which relieved the state of the burden of regulating and maintaining them. This indeed resulted in lower costs on the part of the state, but was based on the assumption that market mechanisms operate public services more efficiently than the state does. In the American civil service, which were from the beginnings based on the culture of business and management, the American neoliberal approach could be successful, however, a similar outcome in Europe was seriously questioned by many people. ${ }^{11}$

The "New Public Management" that had worked out the practical methods for American neo-liberalism has three segments:

(1) Principle of "more market and less state", which aims to strengthen the market mechanism, such as privatization, market competition, deregulation, and the elimination of monopolies, etc. in the public sector. The government should withdraw from the welfare sphere, too, so that the competiveness of the business firms should be increased, due to the lower taxes.

(2) Application of the "business principles in the government sector" in the way of contracting out, and public private partnership. The former one aims to give the right to operate certain government tasks to business firms, such as cleaning at a public authority, maintaining jails, etc., and the latter one establishes a cooperation between the government and the business sphere in the field of government investments.

(3) The "management methods", such as decentralization of the decision making process, the planning, the new public leadership, the public policy, the human resources management, the quality-oriented methods, etc., which were mostly used in the business enterprises earlier, should increasingly be applied in the public sector, as well.

The New Public Management found that a smaller and cheaper state could also be achieved by rationalizing the operation of public administration bodies by applying various "methods", developed by the science of organization, e.g. achievement-oriented budget, and public leadership (Kramer, 2007; Morse \& Buss, 2008), breaking away from the traditions of hierarchical leadership. Currently, the most far-reaching methods, although no longer used by the New Public Management, are "public administration online" and deregulation, the removal of unnecessary statutory provisions from public administration law, especially those related to enterprises.

Statistical data show that the neoliberal economic approach did lead to the reduction of state expenses relative to state expenses of the 1980s. However, they increased to some extent (Lörincz, 2009). This, however, as we have already mentioned, does not necessarily imply that attempts at creating a smaller and cheaper state are by definition hopeless. Today, in certain subareas of the public sector, the extent of cost reduction achieved (e.g., by offering online services by authorities, by reducing the administrative burdens of enterprises in public

\footnotetext{
11 Lörincz (2005) expounds that in European public administration, the aspects of industrial and commercial administration are not enforceable, and it is law that ought to become victorious in the struggle between law and efficiency. In America the outcome is not so obvious.
} 
administration supervision, or by the liberalization of public services), is quantitatively measurable (Kovácsy \& Orbán, 2005). If we, however, also consider that the scope of state responsibilities has broadened (e.g. by regulating financial market bodies, environmental protection bodies and consumer protection bodies, by establishing law enforcement and defense responsibilities, and the system of anti-corruption organizations), the small-scale growth of state expenses does not mean that reform attempts at decreasing state expenses have been inefficient.

Another condition for state efficiency, besides the smaller and cheaper state, is that the intended result, i.e. the target set by the state, be achieved. While the objectives concerning state activity are relatively well-definable, e.g. state costs should be decreased, statutes should be appropriate, public services should be of good quality, the application of law should be fast and flexible, and the economic policy be adequate and reliable, the actual attainment of these objectives is more difficult to assess.

There is no method that could in general assess state efficiency, but regarding individual types of state activity there are methods, by which the result — the quality of the state's activity — can be clearly measured.

The American New Public Management also has quality-oriented techniques to measure state services on the basis of customer and consumer satisfaction, which is not necessarily an objective method in the public sector, yet there are other more tangible factors of measurement as well, e.g., less standing in line, faster administration, online administration, etc. (Kovácsy \& Orbán, 2005).

The public policy approach (Hajnal, 2003) of American origin has so far been the most far-reaching approach, including those of European origin. Public policy-making means the combined application of methods based on scientific results, aiming at efficiently performing the state's public responsibilities, by focusing on the process itself. It characteristically uses the methods of various disciplines, and beyond the application of management methods, it analyzes political, legal, economic and cultural impacts as well. State responsibilities to be performed are selected in specific ways: by conducting opinion surveys, on the basis of interest group activities, or by statistical and economic analyses. Following this selection, the possibilities and limitations of the proposed solution are determined and alternatives offered. This is the basis for the state body to reach its own decision, whose implementation is then subjected to continuous analysis and the output is assessed. The achievement assessment is based on the extent of the actual achievement relative to the impact analyses developed earlier and cost efficiency calculations.

As a result of the crisis of the neoliberal economic policy, the New Public Management argument for a drastic reduction of the state's role has in recent decades been increasingly seen as one of the factors responsible for the development of the weak state, with limited power, being unable to lead (Lörincz, 2007). In this sense, the concept of the efficient state tends to more and more embrace the strong state, too, which firmly and rapidly solves the business of public interest.

Despite the fact that neoliberal economic thinking has in the past decade been generally rejected, the "baby has not been thrown out with the bathwater", and the requirement for the efficient state has not decreased.

On the contrary, efficiency considerations have become emphasized in European states, too, due to economic interests: budgetary indicators, the extent of the state debt, the innovative capacity of the economy, regional development and sustainable development; all are economic aspects that are only enforceable by efficient state action. 
Neo-liberalism has been rejected by Europe much more because it characterizes economic austerity, i.e. cutting back the welfare state and the rolling back of the state's regulatory role in the market system.

The efficiency solutions of New Public Management, supplemented with new content ${ }^{12}$ are currently in their second bloom in Europe (Jenei, 2009). Besides the application of business principles and management techniques, the external and internal supervision of state decisions-openness, transparency, accountability, computability, the balance of political and professional aspects, the state being a provider of services, accesshave been emphasized more.

\section{Public Administration Being Bound by Law and Efficiency}

The Weberian model of public administration - as we referred to it in the first chapter of the paperevolved from the 19th century onwards, meaning centralized, legally-bound public administration, resting on the duality of public and private law.

At the time of liberal capitalism, when public administration based upon the Weberian model evolved, the state's freedom of action was limited by the principles of the rule of law. At that time, the state's being bound by law did not seem to be an obstacle to the fast and efficient execution of the will of the state, since the state was expected not to interfere with economic processes, limit its role to supervise compliance with economic rules of the game and maintain public order.

From the end of the 19th century onwards, the state was responsible for solving economic anomalies, as a consequence of which the state's role in influencing the economy grew. Competition law and consumer protection law were established and, for reasons of ensuring quality and safety, the state included economic activity more and more into its scope of regulation. From then on state responsibilities were extended to the functions of public provision and care-taking: The state organized infrastructural public services through its public utilities or by granting state subsidies to private enterprises and operated welfare institutions.

In European public administration law, this induced two directional changes. Recognizing the need for state intervention, European public administration, as bound by law, legally regulated the means of state intervention in as detailed a manner as possible, continuing to remember the principle that public administration may only do what it is authorized to do by statute. Then the doctrine of legal regulations governing the application of law by authorities and the organization of public services was developed further. The latter, although devoting much attention to it, could nevertheless not provide a solution in the civil service resting on the duality of public and private law as to whether the contract concluded between the enterprise operating the public service and the civil service body on the one hand and the legal status of the enterprise on the other should be governed by public law or private law, and how the elements of these two branches of law ought to be combined. This presented a difficulty for the legal doctrine of public administration, especially when the provision of public services was linked to state property.

This was the age that also marked the beginning of "non-parliamentary legislation" becoming dominant in Europe. Through non-parliamentary legislation, public administration could increasingly gain a primary role in regulating economic relations with laws only governing general issues. This was due to the fact that the parliament, with economic processes becoming complicated, was less and less able to reach fast decisions on

\footnotetext{
12 The basis for the publication was OECD research, summarizing the most recent experience of OECD member states. One of its most important conclusions is that the application of achievement management and market mechanisms has become established practice in OECD countries, but in recent decades, new solutions related to efficiency have also evolved (Lőrincz, 2009).
} 
issues requiring technical expertise.

From the beginning of the 20th century onwards it, became more and more apparent that the requirements of the rule of law for the legal regulation of public administration were burdensome: the requirement to adhere to the rule of law and the supervisory role of parliament had a braking effect on the state's ability to solve problems of public interest fast and successfully (Lörincz, 2010b, p. 265).

In America, at the end of the 19th century for the first time, it was the constitution itself that authorized the government to regulate the economy, on which basis then the Supreme Court developed the boundaries of state intervention. An important difference between the legal regulation in Europe and in America is that, in the American practice, the performance of public responsibilities was not regulated by legal means, since public administration from early on was characterized by the principles of private administration, and legal regulation played no significant role. Legal regulation to this day has been limited to regulating economic activities, e.g. the supervision of competition (antitrust law), the supervision of the financial markets, consumer protection, environmental protection, etc. In the infrastructural sector of public service provision, which in order to meet competition requirements from the beginnings functioned together with business enterprises, pricing regulations were introduced, or state subsidies granted. Welfare services in the American public administration did not become institutionalized and neither were social rights mentioned among the fundamental rights in the American constitution.

The issue of the conflict between the efficient state and the state under the rule of law arose in Europe, at the end of the 1980s with the rise of American neo-liberalism, when research began into whether business and management principles broadly applied in practice could be accepted by Weberian public administration and the American public administration culture.

The first argument presented by opponents to the application of the New Public Management was that it was only a centralized public administration bound by law, having originally evolved in Europe that was suited to represent the public interest (Lörincz, 1999). There is no definition, however, of what is to be considered the "public interest", 13 beyond the simple fact that in European public administration it is the government that determines public interest, to be implemented by the public administration based on hierarchy and legal regulations.

In American public administration, according to the theory of the New Public Management, public interest, as formed by the lobby activity of the business sphere and of the middle classes, actually equals the efficiency of public administration enforceable only by the principles of market management and not by the government. In European view of public administration, efficiency, as one of the possible public interest objectives, can only develop into public interest, as represented by the government, when decisively supported by public opinion and when the government is also motivated by economic pressure.

Those concerned for the traditions of European public administration also argued that public administration in Europe, due to being politically determined, did not comply with the principle of profit, but by considerations as determined by politics. Therefore, organizing the civil service according to the business approach would give the green light to excessive economic influence, which would in turn weaken the civil

\footnotetext{
13 According to the European way of thinking, the definition of the current public interest is the government's political responsibility. In the American view the election programs of the political parties are too general, and offer broad opportunities for the government to determine the current public interest. This is why it is essential in America for lobbies to actively partake in formulating the current public interest (Kenneth, Berry, \& Goldman, 2005, pp. 322-357).
} 
service and the enforcement of the public interest as represented by politics (Lörincz, 2006, p. 644).

It is a fact that public administration in America has never been substantially separated from the private sphere, therefore the New Public Management did not consider the features of public administration to be much different from those of the business sphere, which could have rendered the application of business principles more difficult. The American civil service is also politically less determined, due to the American democracy's traditions of lobbying activity.

The public goals are implemented in the way of public law regulations in the Weberian-based public administration systems - as opposed to the American public administration, where the public authorities, even without being obligated by laws, are forced to implement public goals determined by public polices - the European public administration can act only if it is entitled by the laws to do so. For example, the public policy view is manifested in the requirements of quality legislation, the participation of the business sphere in implementing public goals is regulated by the public procurement laws, and the cogent conditions of the contracts or entry to the market is determined by the concession and the permits, the decrease of administrative costs of firms is managed by deregulation programs, and the e-government feature of the administrative authority is implemented.

The most watertight reasoning against the European application of the New Public Management is the different culture of public administration (Lörincz, 2006, p. 644). In America, public policy objectives are strong incentives for public administration, even though no law binds it to enforce them. Public administration in Europe, in contrast, solves a problem of public interest by adopting a law for the relevant area, then providing detailed regulations for the organization, the institutions and the procedural rules. For the American public administration, according to its traditions, the most important consideration is to be able to successfully discharge public responsibility, while also being under pressure to this end by public opinion. The European approach is, however, much more determined to focus on the precise compliance with statutes, and less on monitoring the actual outcome. It also wants to legally regulate the requirement of efficiency itself, if that is presumed to be the government's intention, in that it obliges public administrative bodies to take account of efficiency, or sets up organizations for achieving and supervising it. ${ }^{14}$

The impact exercised by the New Public Management on the European civil service provides a much more varied picture when the types of public administration are separately examined.

Weberian public administration offered a model for public administration still mainly performing law enforcement duties, at a time when legality and being bound by law were the most appropriate principles. This is unquestionably still true for the application of law by authorities today, too.

It is beyond doubt that for the provision of service provisions by the public administration, efficiency is much more relevant than the Weberian principles. For all areas of public administration, the provision of services has become the prevalent element. Even administration by authorities is more and more considered to be a service and is expected to be fast, flexible, client-centered and online.

Concerning infrastructural public services, in the mid-1990s, the European Union announced that market competition, private property and profit interests resulted in "more efficient" operation in this sector, and bound member states to liberalize their markets. It was in this area of public service where the American business

\footnotetext{
14 The act on legislation obliges the preparer of the statute to assess the possible consequences of the statute through a preliminary impact assessment and assess the actual impact in the framework of post impact assessment, as well as to set the aspects of analysis.
} 
approach based on market competition and self-interest (profit) was most successfully applied.

In healthcare, too, greater emphasis was laid on becoming efficient, applying funding incentives, rationalizing patient routes, making patient routes online, implementing telemedicine solutions or introducing limited market competition. Thus, in healthcare services it was no longer legal regulations governing the competence of the public administration body, or the conditions for utilizing the service, that were essential, but rather low costs and good quality.

The government's economic policies can also not be characterized by principles of the Weberian model, and in most instances cannot be regulated by legal means. In the European practice, too, government programs are accomplished more and more in accordance with the public policy approach.

The budgetary policy, although it is enshrined in an Act of Parliament, has economic content, as well as the monetary policy, independent of whether the central bank is authorized to adopt non-parliamentary legislation or not. These statutes are naturally of economic content, especially since the laws themselves set economic considerations, e.g. fundability and financial stability, as the basic principles to be observed by legal regulations. Even the most "legal" competition law contains mainly only general statements in order for the government's competition policy to be enforceable in the practice of the application of law.

Naturally, this does not question the importance of organizational-procedural safeguards, since legal regulation is essential to establishing the procedure of adopting the budgetary act, the organization and legal status of the central bank, or the procedural rules of supervising competition.

The government's "economic programs", e.g. workplace creation, supporting small- and medium-sized enterprises domestically, employment or regional development, are not primarily subject to legal regulations, but are rather issues of public policy and funding allocation.

The areas where the accurate definition of legal norms and detailed legal regulation are important conditions of implementation are perhaps mainly in the government's "income and social welfare policies". For example, in order to achieve the objective of a higher income, to abolish non-payment in public transport vehicles, and to rationalize the utilization of social welfare expenses, it is important to introduce regulations to establish the order of community service, for who may receive a family tax concession, what the requirements of receiving a disability pension are, or what the rules of computing the pension are.

The management of state property and the utilization of public funds are the most debated areas in Europe regarding the application of business principles. General public opinion regards them as the hotbed of corruption - and these beliefs are not unfounded.

Concession has hardly any significance today, considering that infrastructural public services have mainly been liberalized. Public Private Partnership (PPP) investments of American origin, as well as the contracting out of public administration responsibilities, have now become of central importance. The basic issue for both of these solutions is whether the public administration body can conclude a contract with the business enterprise with favorable provisions for the state, and whether it has sufficient means to achieve the target. Therefore, the considerations and principles are established for these contracts, and "independent supervisory bodies" are created to monitor the process of contracting from the beginning of the business negotiations to completion of the contract. PPP and contracting out are concerned with business issues, and are neither mainly subject to legal regulations. The lesson learned in Hungary concerning concession and the detailed legal regulation of public procurement is that even the most perfect legal regulation is evadable, if it is not properly supervised or when abuses are left without legal consequences, i.e. when the requirement of accountability is 
not met.

The same applies to privatization, which, following the privatization of enterprises which are state property, are of a lesser significance in ex-socialist countries. Privatization is also a business decision by the state, which, however, requires safeguards, such as constitutional regulation, tendering and procedural rules.

Public administration regulation in American terminology does not denote legal regulations, but restricting economic activities to fulfill certain standards of quality, safety, consumer protection, environmental protection, market protection, healthcare, etc. The institutions of procedural law for the civil service for these are e.g. granting licenses, monitoring or supervision. Regulation has increasing significance, especially as a result of the world economic crisis caused by American financial organizations and environmental disasters. This is the area of public administration activities, besides law application by authorities that requires accurate and detailed regulation by substantive law.

The requirement for efficiency has also arisen for non-parliamentary legislation and law application by authorities in European civil service systems.

High quality legislation is increasingly emphasized in the EU, the various methods for which have been worked out: publicity, the involvement of citizens and NGOs, multi-element negotiations between public administration bodies, the adequate transposition of the political decision into the language of law, compliance with the rules of statute drafting, preparing impact studies, and elaborating the methods of implementation (Drinóczi, 2010). Certain features of the American public policy approach can be easily recognized in these methods.

Consequently, efficiency, as a goal of public policy, has been achieved in the Weberian model by way of legal regulation.

Public law in the European legally bounded and over-regulated public administration, can not only hinder the efficiency, but serve the requirements of efficiency, as well. There are important issues, such as guaranties of regulating the scope and procedures of the public authorities, control, supervision and check, regulation of economic activities, but more generally, the principle that the public administration can act only if it is entitled by law, and only within the law's framework, are all important conditions of the efficient operation of the public administration.

If the law has become overgrown and bureaucratic, it can be adjusted to the requirements of efficiency by the means of quality legislation.

Deregulation, the removal of excessive public administration law, is becoming more and more efficiency-oriented. The administrative burdens of enterprises, e.g. licensing, supervision, archiving, data provision, registration, can be decreased, and the economic activity can be made more effective even on the level of the national economy, if for rationalization purposes the laws regulating the unnecessary obligations of enterprises are removed (Drinóczi, 2010, pp. 55-108). Deregulation in this sense, constitutes part of high-quality legislation.

"Cloud Computing" applied first by the Obama administration, but currently gaining ground in Europe, too, aims at the provision of a full-range online services in public administration, whose essence is that anyone may easily access e-services operated from one center, may administer their official business, deliver their payment obligations, download data of public interest, access public services and can keep in touch with public administration bodies through a web-based communication system (Vaquero, Roedro Merino, Garaces, \& Lindner, 2009). Apart from the fact that this system spectacularly decreases public administration costs, it also 
makes official administration client-centered and constitutes a significant step forward to open and transparent public administration. A condition for its application in civil service systems in Europe is the transformation of legal regulations in a way that client routes may be adapted to electronic solutions. ${ }^{15}$ In the internal operation of public administrative bodies, the organizational methods aiming at efficiency worked out by the American New Public Management have been applied in Western Europe ever since the 1980s. Also, in recent years the inner procedures of the public administrative bodies and the interconnections between public administrative bodies have been offered online.

The conclusion drawn from the European practice of the most recent decades is that in the Weberian public administration model, numerous institutions evolved that have laid primary emphasis on efficiency and not on legal regulations. As an effect of this, a Neo-Weberian model (Geert, 2009) is now in the process of being formed. According to this model, European states develop institutions that make state functioning more efficient, while they adhere to the traditions and the framework of European public administration, acknowledging the fact that the business and management methods applied in the American public administration in their original form cannot be directly and totally applied in the European civil service systems, while the Weberian model is outdated and not suited to efficiency requirements.

It is important to emphasize, however, that even though the traditional Weberian model is in many respects not applicable for achieving the new type of efficiency targets, legal regulations themselves can serve the purpose of efficiency. The traditional Weberian model has values, e.g., procedural safeguards: the monitoring of economic activities or the public law and cogent elements of contracts, which in European public administration culture are important conditions for efficiency that are beyond the traditional values of a business culture.

\section{Political and Legal Framework of the Efficient State in Hungary}

As has been mentioned already, despite the fact that it represents a completely new public service culture, several elements of the New Public Management became part of the European public administration systems. The neo-liberalism which was keen to pull the state out from public administration, emphasized the role of market and allowed more room for market mechanisms after the global economic crisis started in 2007 has generally been refused. At the same time, the denial of the concept of the non-intervening state has been replaced by the requirement for a strong and effective state which is, taking emphasis to the interest of national economy, able to support economic prosperity and the well-being of individuals (Bordas, 2014, pp. 18-19).

In the rhetoric of the Hungarian Government, the principle of a strong state has important priorities: the economic policy which reflects the lifelong national interest to break with the tradition based on austerity in order to emphasize individual well-being enhancement of income levels and rate of employment. It gives high priority to the right of self-determination of the state on the economic issue meanwhile the independence of economic policy vis-à-vis the international financial organizations (Lentner, 2013, pp. 29-40).

The Government thinks this economic policy, contrary to the neoliberal economic policy of the former social-liberal governments and reinforced by the authorization of its two-third parliamentary majority, to be the only correct alternative (Lentner, 2013a, p. 314). The Government, for the execution of this policy, considers it

\footnotetext{
${ }^{15}$ Government offices established in 2010 also serve the purpose of offering online services by integrating devolved bodies into one center. This, although an important organizational transformation, is the first step. The adjustment of the process of administration to electronic solutions needs also to be enshrined in legal regulations.
} 
absolutely necessary to create such an organization of the state to carry out the central decisions in a very consistent manner (Lentner, 2013b). The concentration of power, according to the Government's view, is not aiming at the elimination of the state under the rule of law, but seeing just a fast and effective tool for the implementation of governmental policy.

Consequently, the issue can be raised from a political perspective where the implementation of governmental economic policy is based on the end justifying the means: namely the establishment of the so-called "central field of power". 16

In the Hungarian political system, taking into account the lurid opposition of the two political sides and their inability to achieve consensus, can be found some rational arguments against the dual system, and for the support of "central field of power" as well. The buildup of the "central field of power" as the process of formation of a political power system can be observed in the foregoing activities of the Government.

The centralization intention of the Government is based on three pillars: ${ }^{17}$

The rapid and clear implementation of governmental decisions for which the two-third majority was not enough - became necessary in order to implement governmental policy so that they in the short term can be manageable. The tools for it are:

(1) Strict control over the legislation process with the elimination of the rules of legislative process, which has limited debate between members of Parliament and harmonization with ministries and professional agencies;

(2) After the cutback of the norms on controlling authorization of the Constitutional Court, the overview from the constitutional aspects of newly-created laws cannot hold the final approval anymore. Above all, this process has been facilitated by the former and recent president of republic, who did not or just did not formally use the right to request the preliminary constitutional control over the legal issues;

(3) With the background grip of the central controlling organizations-which was the main tool for enlargement of political prize's system - the efficiency, thrift aspects and expediency analyzing over the economic decisions has been eliminated;

(4) Centralizing public administration and changing personnel staff by using the aspect of loyalty aimed at the implementation of centrally-made decisions should be unhampered at the local and regional levels as well.

All these were thought to be necessary for the implementation of the economic policy of the Government, referring to the fact that the accomplishment of electoral promises encourages the government not to apply any restriction vis-à-vis the population. So its economic policy, based upon supposed economic development, cannot be hampered by the aspects of decentralization, economic constitutionalism and self-governance. This

\footnotetext{
16 The Hungarian prime minister, Viktor Orban defined the theory of "central field of power" in his famous "Kötcse speech" spoken in September 5, 2009. According to his starting point, the people consider that the neo- liberal elite have failed, because they steered the economy and society into a bad situation. The neo-liberal elite believed in the omnipotence of the market and financed its political power from the income of privatization and state-credits. These resources have been exhausted. They created a lower class which depends on the state, lives from state allowances, and serves as their voting base. Their ideology, which supported the establishment of their own media-realm and intelligentsia-parasenele, emphasized the superiority of leftwing ideas. Therefore, the political power-system of the so-called left-wing liberal elite fed on three sources: money, ideology and votes. The constant debate on values between the leftwing and rightwing political parties during the last 20 years led to a sharpened political fight, and resulted in a divided Hungary. This dual system should be changed with the "central field of power" in the coming decades. A powerful governing party will develop in the "central field of power", i.e. narrow elite, which will be able to represent and determine the issues based on national interest. The "central field of power" has to minimize the opportunity of the re-establishment of the dual system, in order to assure stable governance, instead of a constant politically based fight.

17 Kötcse speech" by the recent prime minister.
} 
can be done only by the background grip of checks and balances together with centralization of the state-system. This was thought to be a basic condition for, as a main political goal, keeping voter support.

(1) The enhancement of right wing ideological influence has been carried out in many areas:

(2) The regulations of the new Constitution - reasoning of creation and formalities of celebration as well - have paid great importance of the right wing ideology, Hungarian history and identity, the tenet of Saint Crown and the declaration of joining forces.

(3) The state has extended its influence to the area of culture and science. Examples manifesting this are the reorganization of the Hungarian Scientific Academy, the limitation of the autonomy of higher education, the "secularization" of the public education, and the promotion of only "loyal" personnel to the leading posts of cultural and art institutions.

(4) The law of media has been strongly criticized because of the overly broad scope of authority of the Media Office. According to some opinions, it is a clear oppression of the left wing media and it was aimed at the establishment of a right wing media realm. ${ }^{18}$

(5) The churches seem to be very important vehicles for delivering the right wing ideology, which cooperate with the state very closely, too. The Law on Churches has been challenged and criticized harshly because it unreasonably discriminated between churches.

(6) The goal of economic measures of Government with taking under political control the economy has three main economic purposes.

(7) The government, without the influences of international financial organizations, is going to create an economic policy expressing the national interests which is represented by Hungarian undertakings and gives a clear emphasis to the work, not the social aid.

(8) One of the conditions for enhancement of economic efficiency is that the smaller state fulfilled by organizational rationalization, e.g. cutting dawn the personnel staff, central delivery of financial sources, monopolization of several infrastructural public services and economic activities, or using the informatics, etc, can be achieved.

Build up an economic halo by augmentation of state property, nationalization of certain business firms, limitation of the conditions of competition in the market, centralization of the financial sources of the reason for the creation of the "central field of power" is that in the so-called "dual field of power", the neoliberal economic policy of left-wing liberal elite and the national economic policy of the right-wing elite are antagonistic, so that a long-term public policy cannot be formed, because the central willingness is dividing in the "dual field of power". This has been confirmed by the experiences of the last 20 years. The political legitimacy to the recent Government is given by the majority of electors who are supporting the national politics. Consequently the right-wing economic policy should be considered as the policy of public interest. For its implementation, a power structure should be built up in which democracy based on consensus has been changed by majority democracy.

Hereinafter we are analyzing the issue of aspects of politics from the perspective of how it is able to overwhelm the central organizations of state power and the public administration, and to what extent is able to dominate over the economy? Besides, we are trying to answer the question of how the economy reacts to political intervention, which leaves out constitutional and marketing considerations. Our presumption is that the

${ }_{18}$ Ferenc M. Laszlo: Developing the rightwing media-realm. Interview with Gabor Polyak, hvg.hu, Volume December $27,2011$. 
economy reacts to politics in such a context, and during this reaction the economy deprives the politics of its economic background, the most important base of its legitimacy.

This linkage between the economy, the state and politics can be investigated from another approach: the perspectives of efficiency and state under rules of law as well. Two issues can be seen in this context:

(1) To what extent do the traditional institutions of the state under the rule of law hamper the implementation of such an economic policy, or, how the institutions of the state under the rule of law can be rationally limited in order to achieve the central goal?

(2) If the strong state which achieves its central goals in a rapid and determined manner, can it be effective - in order to fulfill efficiency goals - if the institutions of the state under the rule of law are considered to be the second priority at best?

\section{Characteristics of Governmental Understanding and Practices of the State Under the Rule of Law}

The governmental concept of the strong state cannot supported by the practice of eliminating the state under the rules of law using the arguments of European democratic tradition; however, by using the reasoning of the fast and efficient state's flag as an ideology of its centralization attempt can be more successful.

This public policy has been achieved via legislation, i.e. using legal tools. The strong state build up, as we have already referred to in the introduction, has been achieved during the last almost four years, according to many opinions, by the suppression of the rule of the law, especially the system of checks and balances. It is not easy to determine this process because keeping - at least seemingly - the state under the rule of law could not been questioned in any way, but at the same time, in the background and an intangible way, the power concentration intentions of the government have dominated.

The public law relevance of the legislation practice during the last almost four years is that the line between the governmental centralization efforts and the breach of the state under the rule of law cannot be clearly drawn.

This period is well characterized by the breach of regulating norms of the legislative process and such legislation practice has aimed at figuring out a neglected functionality of legal institutions.

One of the ways to abuse regulating norms of the legislative process is through frequent modification of the constitution with new provisions which removes acts that have been abolished by the Constitutional Court from further constitutional supervision, and the dominance of individual initiatives of the members of parliament regarding legislation used to pass their proposals of acts, which has finally resulted in the legislation being sorted out from under the umbrella of the act on legislation.

For the new legislation, laws created by the government and with effect from 2011, according to European tendencies, have incorporated such elements as the concept of "quality legislation", but in the reality the policy methodology of the public administration, i.e. effect analysis, social conciliation, administrative racks, of the New Public Management has been attained. The legislation, being out from under the umbrella of legislation law, has caused several anomalies of legislation: The system of legal regulation has hence become unclear and incoherent.

The work of law preparation by the government, such as the assurance to be in accordance with public policy, the examination of a law's effects and administrative burdens, the negotiations with non-state actors and professional bodies, etc. normally should aim to enhance the quality of legislation, but in this case it was 
realized that instead, anomalies of legislation prevailed, i.e. the acts passed by the Parliament are often vague and inadequate.

The Constitutional Court has announced in one of its resolutions that the domination of certain members in the parliamentary initiatives is not a constitutional problem if legislative procedures are respected. Therefore, recent legislation, however serving for daily political interest, cannot be challenged and reviewed in this perspective. Invalidity from the aspects of public law can be determined only if the legislative procedure has been breached, but this case is an abuse of legislative power rather than a breach.

From the reasoning of this resolution, it has been clear that the public law basically cannot manage the use of legislation in a functional way. The abuse with legislative power-which should be a breach of the state under the rule of law_-should be understood from a broader viewpoint (Lászl, 2005). From our perspective, the practices of the recent government which have been conducted over the last almost four years, is a clear abuse of legislative power as well; such acts ought to be abolished

Other example of the abuse of legislative power through deviations from legislative procedures can be mentioned, as well. The Parliament, for example, modified the parliamentary rules of the legislation so that proposals containing not only formal modifications but substantial ones as well could be taken to the table before the final approval. With this, proposals for acts cannot be discussed openly anymore in the Parliament, which is a clear violation of the principles of deliberative democracy.

After the Constitutional Court had abolished an act, the Parliament, without any changes, approved it again on the same day. In other cases, when a certain part of an act which evidently would violate the Constitution, or could be challenged by the Constitutional Court as a constitutional problem, will be regulated in the Constitution, even if it is not subject to constitutional regulation. The non-profit character of the certain firms, the limit of state-debt, or the issues of homeless have been regulated in the Constitution by its amendment.

After the Constitutional Court had abolished the legal provision allowing termination of the work contracts for public servants without justification, the Parliament created instead the allowed the practice to continue by creating the criteria of "loss of confidence", which has no adequate legal definitions, so in this way breaches the state of the rule of law.

There are also cases when the new Constitution itself suggests the abuse of legislative power.

According to the new Constitution, the president of republic and the Parliament are authorized to initiate normative pre-supervision of acts, but after the legislative approval of acts, normative supervision can be asked for by the Government, one-quarter of the members of parliament or the Ombudsman. The right to rule on acts based on the conformity with the Constitution belongs to the Constitutional Court.

The Government and the governing party of the Parliament have no interest in asking for constitutional review of certain acts - at least on the basis of the current political tendency it can be seen clearly-the president of republic has neither, as well, regarding that he is a most loyal and oldest founder of the governing party. Regarding the initiative based on one-quarter of the members of parliament requesting, it is not a real option because of the oppositional parties' wide ideological and political gap, it is practically excluded. The newly-elected ombudsman could use his authorization, but most probably this will be also the subject to the loyalty of the personnel.

Against this background, it seems to be difficult to presume that such provisions of the new Constitution do not fit the requirements of actual political interest. The authorization for the Constitutional Court as laid 
down in the new Constitution just barely keeps its function as a balance opposing legislative power. It is a problem not because the constitution maker used his power to cut back the competence (jurisdiction) of the Constitutional Court but because the current political environment gave an ostensible power to the Constitutional Court, but in fact it clearly intended constitutional regulations to be exhausted.

The act on elections can also be suspected to be an abuse of legislative power, because its rules have been promulgated in accordance with the current political force.

The practice of the selection of the leaders and steering committees members of state powering organizations functioning as the counterbalance in public power against the government-which is not a question of legislation but instead an individual decision of the Parliament - is bringing to light the same problem. The Parliament - according to the Constitution — has a right to elect the president of republic, the president and members of Constitutional Court, the ombudsman, the president of Supreme Court and State Audit Office, and also the Public Prosecutor. In the Parliament where the governing party has a two-thirds majority it is sure that the Parliament will elect the candidates nominated by the Government.

The basic functions of the abovementioned state authorities are to serve as the contra-balances vis-à-vis the government and the Parliament. The Hungarian Parliament, having implemented this practice, made this function exhausted. At the same time, it established the Counting Commissioner, who is just responsible for investigation of corruption of the former Government, often under political orders. ${ }^{19}$

The former presidents of republic found no act to have a constitutional problem requiring it to be sent back to the Parliament, and the current one does so rarely, and only in laws of lesser importance. The fact that the six newly-elected constitutional judges have a strong relationship with the governing party also came to light, because their voting and explanations in the resolutions of the Constitutional Court have also been marked by their loyalty, however, earlier such a phenomenon was not present. The former president of the State Audit Office regularly released his reports that criticized the government, but the current one has released zero.

The ostensible reasoning for the firing of the former president of the Supreme Court and the former Ombudsman of Data Protection was the creation of a new organization - the so-called Curia and the National Data Protection and Freedom of Information Office - which needed a new president and a new ombudsman. This is, however, most probably was not a coincidence, but because both of them have made certain criticisms against the government.

It is almost impossible to shed light on the relationship between the loyalty of the leaders and political influence in the operation of prosecution and jurisdiction, because consequences could be drawn only on the basis of the detailed analyzes of the cases with political background. The political influence on the prosecution can be suspected, however, because the courts have founded numerous charges of prosecutors in the cases of political background as insufficient and acquitted the accused.

The changes made in the jurisdiction of the Constitutional Court can be regarded as game-changing in which the power on the regional level has been replaced with the power of the president of the Nationwide Court Office, who has the right to reorganize the structure and staff of justice. It could support the effectiveness of court administration but according to many opinions, the current president, by having a close personnel relationship with the governing party, can use her influence in the cases with political background. This suspicion can be reinforced by the fact that the rights of defense lawyer have been limited in the procedural

19 The Government Controlling Office, supervised directly by the central Government, investigates only the corruption cases of the former government, assuming that the current Government does not have any. 
criminal law and the president of the Nationwide Court Office has got an authorization for the designation the acting court in the concrete cases.

The provisions for termination of work contracts of public servants without any justification, which have been modified to use the terminology "loss of confidence", as a reason for termination can be considered to be a mechanism for the government to cut back the number of public servants without legal limitation, and can also be used as a political "cleansing" tool and to allow followers of the new governing party to be appointed to positions in the name of a "spoils system". According the theorem of public administration, the status of public servants, contrary to the private sector, should be stable and accountable, being judged on only the quality of their work, but not on any political aspects.

The abovementioned examples support the possibility that the personnel policy conducted by the government is one of the tools to eliminate people and controlling institutions that provide checks and balances in the political system and transforming the civil service into that is loyal to a particular government, rather than the government as the servant of the people.

From the legal perspective, it is not really tangible and very difficult to regulate this problem with legal tools. Certain positions - as accepted by the legal system as well—are going to be filled by person selected on a political basis and nominated by political parties. There is no template or gauge by virtue of which we can doubtlessly determine the degree of loyalty to the government. This can be supported by a high level of political culture and political self-limitation, but if these do not work, only with the support of the parties of opposition.

This practice normally should be supervised by the Constitutional Court - to prevent possible abuse of legislative power-but the Constitutional Court itself has just an apparent, but no real, authorization, as well. So the game is over.

To the basic principle of the Constitutional Court "One cannot establish the state under the rule of law against the state under the rule of law", we can add another one: "One cannot establish the efficient state against state under the rule of law, either".

\section{The Relationship Between the Efficiency and the State Under the Rule of Law in Governmental Policy}

The withdrawal of acts from the scope of normal supervision by the Constitutional Court and the Act on Legislation has provided an opening for quick and determined execution of economic policy by the current Government.

It is well known that the reform processes used during the last 20 years have been made ineffective, practically impossible, because of the permanent confrontation of governmental parties and the opposition, where the consensus over the basic reforms requiring a two-thirds of majority in the Parliament, could not be achieved.

The political and legal obstacles are less and less limitations for the current Government so its wishes can be implemented easily. The question of this chapter is whether effective governance can really come into existence in this way?

The budgeting and financial policy of the government is coming about via such legal regulations that have an economic character and can be controlled by constitutional supervision only with difficulty. The goal of constitutional supervision over economic policy is double: harmonizing the constitutional regulations and 
principle of the state under the rule of law and basic constitutional rights, while also bypassing economic processes generated by the government which are against economic rationality. This last mentioned effort-according to the EU legal practice as well-is standing up such requirements for economic governance which is based on the adherence to the law of the market.

Hence, economic constitutionalism includes not only the liberal economic basic rights expressing capitalist economic rules but more and more the aspects of effectiveness and rationality as well. The new Constitution stipulates that numerous economic requirements for such effectiveness should be kept by the leader of budgeting and financial policy and the management of state property but currently these are just a declaration because of the lack of enforcement mechanism for economic constitutionalism and the formal functionality of the Constitutional Court and controlling organizations.

The constitutional norms are not of the "art for art" limitation of economic governance, but from the very early time of liberal capitalism, it has a role for the economic intervention aiming to determine the gaming roles.

The Government, with the withdrawal of economic policy from under the umbrella of constitutional oversight, has generated the view that certain norms of the state under the rule of law-such as checks and balances, use of the legislative power according to rules, clarity of norms, retrospective scope of legislation, the validity of public law legal regulations, protection of obtained rights, achievement of a constitutional level of protection, or the economic basic rights (such as the rights of property, freedom of contracting, rational and proportional contribution, equal treatment) - have been breached during the legislation. All of them make the players of the market too indeterminate, destabilizing the confidence against the government, which is leading to fall off of governmental support. From the other hand, the constitutionalism of the matter is the factor of effectiveness because of its accountability.

At the same time the constitutionalism of economic governance has to be taken into consideration as an efficiency requirement, as well, which can assure an important approach: predictability.

The economic policy of the recent Government has less respected other efficiency requirements: the stability, accountability, or public policy viewpoints. The goals of such an economic policy can be correct but the tools for it are in some cases contrary to the aspects of efficiency. There should be any analysis of the effects or harmonization of interests which could open up the possible reaction of the market, and also, economic policy measures reflecting the actual political goals that resulted, which needed to be continuously corrected.

The law of the market does not really tolerate such factors which can generate unforeseen economic processes in this way.

According to János Kornai (2012), excessive centralization is incompatible with the good functioning of the market, because the centralized decision-making system rewards the implementation of central will but does not allow any opportunity for the market to correct the economic governance. He has determined the centralizing effort of the government and the anomaly generated by its effects to be similar phenomena to the socialist economic administration system and obviously sees as a problem of the governmental economic policy.

Our opinion is that any centralization effort by the government - at least concerning the market—still is not on the level of economic administration system of socialism and even if a strong centralization effort is observed, we cannot say that the government took under control the economic activities in a scope which 
excludes the emergence of market mechanisms. This phenomenon currently can be observed just in some parts of the economy.

In the structure of public administration, the centralization went through via contraction of institutions, ${ }^{20}$ cutting back of responsibility ${ }^{21}$, changing leading personnel of organizations with more loyal ones ${ }^{22}$, limitations of rights of local governments ${ }^{23}$, and the corporatism of trade unions or limitations of their terms of reference. ${ }^{24}$

The nationalization of an economy also signals the tendencies of centralization to take certain local authorities' properties as state property, ${ }^{25}$ or to enhance the proportion of the state property in the businesses. ${ }^{26}$

The nationalization of the economy, however, means a tendency towards centralization, as well, such as the withdrawal of the property from the local governments, or a decrease of the proportion of the state-owned shares in business enterprises. In the framework of the nationalization tendency, the Government declared some economic activities to become state monopolies, or "re-monopolized" 27 others that had been liberalized before, withdrew the concession rights from the competitors of the state, and established unequal conditions (e.g. in public procurement procedures) in the market competition. ${ }^{28}$

This nationalization is typical in the field of delivery of European development resources as well. Besides the so-called Széchényi-project established for the small and medium enterprises, the operative programs financed from the sources of the EU can be used only by central state organizations, which are not really transparent for outsiders. For the business and nonprofit organizations, up to now not one tender has been announced by the Government.

\footnotetext{
${ }^{20}$ Several organization in the public administration were merged, which gave a good opportunity for the central government to put politically appointed leaders to these newly established organizations. Merges occurred in the field of courts, ministries, central bank and banking supervisory authority, tax and custom office, media and telecommunication authorities, health system, health insurance supervising authority, the decentralized authorities and the newly established county government offices, pension insurance office, public education, Hungarian Scientific Academy, public foundations, and the cultural and art institutions.

21 The Office of the State Budget Council was terminated and the number of the ombudsman was decreased from 4 to 1 . The Data Protection Authority has been responsible for data protection, not the ombudsman, as it was before.

${ }^{22}$ As it was mentioned earlier, persons loyal to the government were appointed to almost every public position, e.g. the president of the republic, constitutional judges, chief public prosecutor, president of the Supreme Court and the Nationwide Office of the Courts, members of the Monetary Council, president of the Banking Supervisory authority, president of the Data Protection Office, the public media, university rectors, public school directors, hospital directors, the director of the Opera House and the New Theatre, etc.

${ }^{23}$ The tasks to maintain public schools, and health care institutions, were withdrawn from the scope of local governments. Properties used for these tasks became property of the state. According to the provisions of the new Constitution, it is the right of the state authorities to nationalize property of the local governments, at the same time, the property rights of local governments were limited by new constitutional regulations, compared to the older Constitution. The Committee of the European Regions is anxious about such an egregious limitation of the rights of local governments ("The European Union could find a new catch on the Constitution” Nepszava, Volume 23/January, 2012.)

${ }^{24}$ The aim of the Government, through establishment of the Hungarian Police Association, was to replace the trade unions with a new representative organization under state control. The new labor laws have significantly limited trade union rights.

${ }^{25}$ Public schools' and hospitals' properties were re-allocated to the state.

26 The Government bought the majority shares of several business enterprises in some fields of the economy, such as gas, electricity, petrol, banks, airline, etc.

27 It has been a constant scandal in Hungary that the Government monopolized the agricultural fields, the tobacco trade, and gave them to people loyal to the government in unfair tenders. The former owner or possessors were deprived from their business.

28 The telecommunication services were previously liberalized economic activities, but as a result of the "nationalization", some services, such as the mobile payment and the electronic case management, have been declared state monopolies. The Government then established a new state-owned enterprise for mobile service providers. However, the state did not ensure equal opportunity for other business enterprises. The European Committee began its investigation to decide if public tender was managed by the state authorities in a fair way, and if the competition in the market of mobile service providers meets the requirements of the EU laws. That is, the new regulations can easily remove the other three mobile service providers from the market. The Government withdrew some concessions of mobile service providers, such as Telecom and Telenor and established state-owned enterprises in the field of the former concessions.
} 
The reasoning of the centralization - the public administrative organization's contraction and nationalization of economy — was the unification of tendering, the rational delivery of development resources, implementation of reforms in a unified manner, rationalization of terms of reference of organizations and also the facilitation of digitalization of public service.

All of those could imply an efficiency aspect. This efficiency policy can be interpreted as the negation of methods applying business principles to public administration. The coating of the business sphere - PPP investment and outsourcing of public tasks - has been radically limited by the government and also different areas of economy have been taken over by the government.

These nationalizations in the economy seem to distort the conditions of competition, resulting in a well determined economical oligarchy that is going to be dominant in certain parts of the economy.

Several other examples can be mentioned, too, of how the measures taken by the Government were turned in the opposite direction than intended by the regularity of the market processes. All of these attempts can be characterized as less adequate economic decisions.

The monetary policy could not have been controlled by the Government anyway, because the independence of the central bank is heavily protected by the EU laws. So, the effort of the Government to limit the scope of the president of the central bank by reorganizing it has come up against the very strong opposition of the European Union that the Government had to retire. The scope of duties of the president of the central bank remained untouchable until the end of his appointment. Then the Government appointed the minister of economics to this position, assuring in this way that the Central Bank will follow a fiscal policy in accordance with the will of the Government. As a result, the entire fiscal policy was put under total control of the state.

The aim of the 'crisis taxes' imposed on multinational enterprises and banks was to avoid restrictions disadvantageous for the people, but put a heavy burden on the multinational enterprises and banks, so that they shared in the costs of the economic crisis. The multinational enterprises were forced to fire some of their employees in order to compensate for the loss they suffered.

The Government nationalized the private pension system, as well, which in fact aimed to decrease the loss of the state budget.

Furthermore, the abovementioned kinds of fiscal policy have not convinced the European Union that these incomes will solve the problem of the loss of the state budget for a long term.

The implementation of the flat rate of tax, which originally aimed to strengthen the middle class, was not previously examined to see if it was capable of increasing the internal demand, which was thought by the Government to be the result. As an economic consequence, economic growth did not happen, but the loss of the state budget, because of the lower income of the state budget, increased. The Government had no other choice but to amend the flat rate of tax more times, which stopped to be flat rate tax anymore, but instead made the tax system extremely complicated.

Introduction of the flat rate tax, together with inflation, decreased the income of the poor, so the Government pressured business enterprises to compensate for this situation by increasing wages, threatening them exclusion from public procurements if they did not. The Government later gave the opportunity for the business enterprises to apply for financial support from the state for their wage compensations.

The aforementioned measures of the Government, such as the crisis taxes, and the compensation for the flat-rate tax, decreased the profits of the business enterprises, which narrowed down the sources of the economic growth, and at the same time, that of the mover, the investments. As a reaction to the burdens 
imposed on the banking sector, the banks began to decrease their credit supply, which also hindered investments by business enterprises.

The business enterprises felt these unpredictable and inadequate economic decisions put them at the mercy of the Government, so the Government is going to lose the trust of the market. Right now, the Hungarian economy is considered by the international financial market to be a higher risk for foreign investors. This tendency further decreases the foreign capital investments and weakens the financial market in Hungary. As a result, the economy did not growth so quickly, as it was expected, and the loss of the state budget could not be decreased essentially. However, the loss of the state budget remained under 3\%, as it is required by the economic policy of the European Union. Also, the economic growth has been close to the 3\% by 2014 .

The original aim of the Government was to avoid the restrictions in order to increase the living standard of the people. The unfavorable economic processes, however, forced the Government to compensate for the loss of the state budget by implementing restrictions, such as higher taxes, tuition fees in higher education, narrowing the right to pensions, eliminating several social aids, and introducing public work; however, it was presented by the government rhetoric as the rationalization of the economic measures. The level of employment did not increase in the business sector, and the level of income decreased, as well. The latter one, to a certain extent was compensated by the decrease of the fees of the electricity and the gas supplies, which has been evidently popular among the population. This was one of the reasons for the Government why it could win the elections in 2014.

The Government's economic measures have had just the opposite effect than was intended. This kind of economic policy became unacceptable for international organizations, e.g. the International Monetary Fund, not because it broke with neoliberal principles, and emphasized national economic interests, or because the economy would have been driven to a deep recession, but because it became discredited. This is evidently in close connection with the falling of economic constitutionalism into the background.

According to the standpoint of the government policy, the aforementioned economic measures were necessary so that the serious economic crisis developed by 2010, could be managed. This economic policy of the recent government is called as "unorthodox", which is based on the expectation of the strong economic governance that can correct the serious faults of the neoliberal economic policy of the former socialist-liberal governments (Lentner, 2010).

\section{Conclusions}

The study has tried to shed light on the process how the Government centralized its political power in order to quickly and efficiently implement its economic policy, but has seen the state under the rule of law and the economic constitutionalism as the limitations of its will, and therefore treated them as to be of minor importance.

Constitutional principles, such as checks and balance, level of the constitutional protection, criteria of the state under the rule of law and human rights, etc., as developed in the interpretation of the Constitutional Court, can be mentioned as examples. Taking out of consideration these constitutional principles-from the protection of the Constitutional Court-jeopardizes the stability and predictability of economic legislation, which is otherwise supposed to be the most important issue of economic governance.

Not only the constitutional principles, but at the same time efficiency requirements that had been built earlier into the norms of the state under the rule of law, e.g., the high quality requirements of the legislation, 
were overshadowed in this way. Disregard of the act on legislation, aimed at a quick implementation of the central political decisions, is based on current political interests in the process of legislation. The Government, for this reason, sacrificed the public policy view, too, e.g. examination of the effects, cooperation with interest groups, evaluation of implementation, professional discussion with public authorities, etc., which has resulted in inadequate economic measures, and at the same time, a low efficient of economic governance.

The elimination of checks and balances, together with centralization tendencies aimed at that the central political decision, did not have objections to its implementation anymore. Such phenomena seriously jeopardize as well as the integrity of the public administration.

Regarding the efficient state and the state under the rule of law in the practice of the Government, a conclusion can be made that the baby has been poured out with the bathwater, too, because the Government kept only the implementation of the central political decisions in its view. This is because the existence of efficiency requirements can prevail only together with the guarantees of state under the rule of law. In other words, implementation of economic policy by all means, as the end cannot justify the means, because the market holds limitation of state under the rule of law as low efficiency of economic governance, and reacts to it with inadequate economic processes.

Consequently, the following conclusion can be drawn based on the analyze of this study: The centralization policy of the recent Government cannot be legitimized by such aspirations, where instead of openly eliminated democratic values especially a state adhering to the rule of law and a system of checks and balances, attempts to establish exhausted legal institutions can be observed and manifested.

The history of economic governance is the history of the dilemma of how state intervention can achieve the economic goal in the way that the processes in the market do not turn completely in the other direction. There is no template and no adequate solution in economics to this problem. The full economic liberty leads to anomalies in the market meanwhile the extreme intervention from the government also - see the socialist planning economy as the extreme example of it—can hamper the effective functionality of economy. Good leadership of economy — in the general term — employs adequate adaptation to the processes on the market.

\section{References}

Ádám, A. (1999). Public administration bound by value in a constitutional state under the rule of law. Tér és Társadalom, 3 , $19-20$.

Bordás, M. (2009). The economics of public administration-The possibilities and dilemmas of economic governance. Budapest: Unió Publishers.

Bordas, M. (2014). The economy of public administration-The opportunities and dilemmas of economic governance (2nd ed,). Dialóg Campus Kiadó, Budapest-Pécs.

Cameron, K. S., \& Wheten, D. A. (1983). Organizational effectiveness. London: Academic Press New York.

Chronowski, N., Drinóczi, T., \& Zeller, J. (2010, December). Beyond the constitution... Közjogi Szemle. Hungarian Public Law Review.

Drinóczi, T. (2010). High quality legislation and the reduction of administrative burdens in Europe. HVG-ORAC.

Fleck, Z. (2008a). State under the rule of law and the judiciary in a changing world. Budapest: Pallas Páholy-Gondolat Publishers.

Fleck, Z. (2008b). Courts evaluated. Budapest: Pallas Publishers Ltd..

Geert, B. (2009, April 24). Changing world, changing public administration: New European trends. Proceedings from "Changing Public Services in a Changing World" Conference. Budapest: Hungarian Parliament about Current Trends in European Public Administration.

Hajnal, G. (2003). Efficiency and achievement in the public administration of EU countries. Paris: Unió Publishers. 
Jenei, G. (2009). The distorted Hungarian processes of the public institution reform on the balance of EU member states: Shortages, causes, solution proposals. In I. Verebélyi \& I. Miklós (Eds.), A better public administration instead of making no progress or a decline (pp. 37-52). Budapest: Századvég Publishers.

Kenneth, J., Berry, J. M., \& Goldman, J. (1995). The challenge of democracy: Government in America. Houghton Mifflin Company, USA.

Kramer, R. (2007). How might action learning be used to develop the emotional intelligence and leadership capacity of public administrators? Journal of Public Administration, 2, 205-229.

Kornai, J. (2012, February 14). Centralization and capitalist economy. Retrieved from http://www.the-american-interest.com/2012/02/14/centralization-and-the-capitalist-market-economy/

Kovácsy, Z., \& Orbán, K. (2005). The assessment analysis of legal regulation. Budapest: Dialóg Campus.

Lászl, K. (2005). Thoughts about the abuse with the power of legislation. Tanulmánykötet Erdösy Emil professzor 80. születésnapja tiszteletére. Szerk.: Balogh Ágnes és Hornyák Szabolcs, PTE ÁJK, Pécs.

Lentner, C. (2010). The Hungarian economy based on market mechanisms is really represents a higher level model than the bureaucratic comminust planned economy? Heller Farkas Füzetek, 8(1-2), 11-13.

Lentner, C. (2013a). Public finance and state budget. Budapest: Nemzeti Közszolgálati Tankönyvkiadó .

Lentner, C. (2013b). Some historical and international aspects of the Hungarian economic crisis and its management. Pénzügyi Szemle, 3, 564-567.

Lőrincz, L. (1999). Public administration yesterday, today and tomorrow. Tér és Társadalom, Volume 3.

Lörincz, L. (2005). The efficient state. Magyar Közigazgatás, 8, 449-450.

Lőrincz, L. (2007). Public administration reforms: Myths and reality. Közigazgatási Szemle (Public Administration Journal), 8, 6-10.

Lörincz, L. (2009). How to modernize public administration? The path to follow. Hungarian Academy of Sciences, Institute of Law, Budapest.

Lörincz, L. (2006). The modernization of government. Magyar Közigazgatás, November 2006, p. 644.

Lörincz, L. (2010a). Efficiency and democracy in the civil service. In N. Tamás and T. Gábor (Eds.), Prudentia Iuris Gentium Potestate-Ceremonial Studies in Honor of Vanda Lamm (pp. 265-266). Hungarian Academy of Sciences, Institute of the Sciences of Law, Budapest.

Lörincz, L. (2010b). Efficiency and democracy in public administration (Prudentia Iuris Gentium Potestate-Ceremonial studies in the honor of Vanda Lamm). Editor: Tamás Nótári and Gábor Török, Hungarian Academy of Sciences, Institute of Law, Budapest.

Lentner, C. (2013). History and scientific systematics of the regulation of banks. In L. Csaba (Eds.), Banking management (pp. 29-40). Budapest: Nemzeti Közszolgálati Tankönyvkiadó.

Morse, R. S., \& Buss, T. F. (2008). Innovations in public leadership development. USA: M.E. Sharpe.

Sári, J. (1992). The principles and values of state organization. In I. Kukorelli (Ed.), Constitutional studies (pp. 160-161). Budapest: Századvég Publishers.

Vaquero, L. M., Roedro Merino, L., Garaces, J., \& Lindner, M. (2009). A break in the clouds: Toward a cloud definition. ACM SIGCOMM Computer Communication Review, 39(1), 50-55. 